Joumal of Antimicrobial Chemotherapy (1992) 30, 327-337

\title{
In-vitro and in-vivo evaluation of the antistaphylococcal activity of S-5556, a new 16-membered macrolide
}

\author{
C. Chuard, P. Rohner, V. Dunand, R. Auckenthaler and D. P. Lew \\ Division of Infectious Diseases, University Hospital, CH-1211, Geneva 4, Switzerland
}

\begin{abstract}
During recent years, a resurgence of interest in the macrolides had led to the discovery of new derivatives of erythromycin with improved antibacterial activity and pharmacokinetic properties. In this study the in-vitro and in-vivo antistaphylococcal activity of S-5556, a 16-membered macrolide, was evaluated. In vitro, S-5556 was slightly less active than erythromycin against methicillin-susceptible Staphylococcus aureus. In contrast, it had superior activity for methicillin-resistant $S$. aureus (MRSA); several of these strains with inducible resistance to the macrolides-lincosamides-streptogramins group were susceptible to S-5556 whereas erythromycin was inactive. The combination of S-5556 with oxacillin was synergic for most MRSA strains tested. In vivo, a single prophylactic dose of S-5556 prevented $75 \%-100 \%$ of the cases of acute staphylococcal subcutaneous foreign body infection in a guinea pig-model. In a rat-model of chronic implant infection due to a methicillin- and erythromycin-resistant $S$. aureus strain, S-5556 significantly decreased the bacterial concentration around the foreign material, however resistant mutants emerged.
\end{abstract}

\section{Introduction}

Erythromycin has been used as an effective and safe antimicrobial agent for nearly four decades. Its spectrum includes numerous Gram-positive bacteria, among them staphylococci (Steibigel, 1990). During the past few years, a resurgence of interest in the macrolides has led to the discovery of several 14, 15-, and 16-membered derivatives of erythromycin with improved properties (Kirst \& Sides, 1989a,b). S-5556 (paranitrobenzyl-oxime-tylosine) is one of the 16-membered compounds described recently (Ruggeri et al., 1989). This study examined S-5556 in vitro and in vivo as an antistaphylococcal agent. First, its inhibitory activity, alone or in combination with other antibiotics, was evaluated against a collection of clinical isolates including methicillinsusceptible and -resistant Staphylococcus aureus and coagulate-negative staphylococci. Secondly, S-5556 was tested as a prophylactic agent in a guinea pig-model of acute subcutaneous foreign body infection caused by a methicillin- and erythromycinsusceptible strain of $S$. aureus (Zimmerli et al., 1982; Tshefu, Zimmerli \& Waldvogel, 1983; Bouchenaki et al., 1990; Vaudaux et al., 1990), and as a therapeutic agent in a rat-model in which a methicillin- and erythromycin-resistant $S$. aureus strain was responsible for a chronic implant infection (Lucet et al., 1990; Chuard et al., 1991a,b). 
Table 1. Comparative in-vitro activity of S-5556 and other antistaphylococcal agents for $S$. aureus and coagulase-negative staphyloccoci

\begin{tabular}{|c|c|c|c|c|}
\hline $\begin{array}{l}\text { Organism } \\
\text { (no. of strains) }\end{array}$ & Agent & $50 \%$ & $\begin{array}{c}\mathrm{MIC}(\mathrm{mg} / \mathrm{L}) \\
90 \%\end{array}$ & Range \\
\hline $\begin{array}{l}\text { Methicillin-susceptible } \\
\text { S. aureus (23) }\end{array}$ & $\begin{array}{l}\text { S-5556 } \\
\text { erythromycin } \\
\text { roxithromycin } \\
\text { penicillin } \\
\text { oxacillin } \\
\text { gentamicin } \\
\text { rifampicin } \\
\text { vancomycin } \\
\text { fleroxacin } \\
\text { ofloxacin }\end{array}$ & $\begin{array}{l}1 \\
0.25 \\
0.5 \\
0.5 \\
0.25 \\
0.25 \\
0-008 \\
1 \\
0.5 \\
0.25\end{array}$ & $\begin{array}{l}1 \\
0.5 \\
0.5 \\
2 \\
1 \\
0.25 \\
0-008 \\
2 \\
0.5 \\
0.25\end{array}$ & $\begin{array}{c}0.25-2 \\
0-25-8 \\
0.25-32 \\
0-03-2 \\
0-12-1 \\
0.12-32 \\
0-004-1 \\
1-2 \\
0-25-0.5 \\
0-12-0.25\end{array}$ \\
\hline $\begin{array}{l}\text { Methicillin-resistant } \\
\text { S. aureus (17) }\end{array}$ & $\begin{array}{l}\text { S-5556 } \\
\text { erythromycin } \\
\text { roxithromycin } \\
\text { penicillin } \\
\text { oxacillin } \\
\text { gentamicin } \\
\text { rifampicin } \\
\text { vancomycin } \\
\text { fleroxacin } \\
\text { ofloxacin }\end{array}$ & $\begin{array}{c}2 \\
32 \\
32 \\
>16 \\
32 \\
0-25 \\
0-008 \\
1 \\
0-5 \\
0-25\end{array}$ & $\begin{aligned}> & 32 \\
> & 32 \\
> & 32 \\
> & 16 \\
> & 32 \\
> & 32 \\
& 0.008 \\
& 2 \\
& 0.5 \\
& 0.25\end{aligned}$ & $\begin{array}{c}1->32 \\
0.25->32 \\
0.5->32 \\
>16 \\
8->32 \\
0.12->32 \\
0-004->0.12 \\
1-2 \\
0.5 \\
0.25-0.5\end{array}$ \\
\hline $\begin{array}{l}\text { Coagulase-negative } \\
\text { staphylococci (16) }\end{array}$ & $\begin{array}{l}\text { S-5556 } \\
\text { erythromycin } \\
\text { roxithromycin } \\
\text { penicillin } \\
\text { oxacillin } \\
\text { gentamicin } \\
\text { rifampicin } \\
\text { vancomycin } \\
\text { fleroxacin } \\
\text { ofloxacin }\end{array}$ & $\begin{array}{l}1 \\
0-25 \\
0-25 \\
0-5 \\
0-25 \\
0-03 \\
0-008 \\
2 \\
0-5 \\
0-25\end{array}$ & $\begin{aligned} &> 32 \\
&> 32 \\
&> 32 \\
& 8 \\
& 32 \\
& 16 \\
& 0-015 \\
& 2 \\
& 1 \\
& 0-25\end{aligned}$ & $\begin{array}{c}0-5->32 \\
0-25->32 \\
0-12->32 \\
0-03->16 \\
0-06->32 \\
0-03->32 \\
0-004-0-015 \\
2 \\
0.5-8 \\
0-25-1\end{array}$ \\
\hline
\end{tabular}

Methods

\section{Antimicrobial agents}

Antibiotic powder of S-5556 was kindly provided by Servier (Neuilly-sur-Seine, France) and the other tested antimicrobials listed in Table I by their respective manufacturers. S-5556 was dissolved in water and the other agents in solvents as recommended by their manufacturers.

\section{Bacteria}

Staphylococcus spp. were selected from a collection of blood culture-isolates of patients with proven septicaemia associated with intravenous device infection. Methicillinresistant $S$. aureus (MRSA) were chosen from a collection described previously (Hemmer, Vaudaux \& Waldvogel, 1979; Vaudaux \& Waldvogel, 1979). All strains were identified to species level with the API 32 Staph strip (API System, Montalieu-Vercieu, France). 
Susceptibility testing

The MICs of each agent for the staphylococci were determined with the agar dilution method recommended by the National Committee for Clinical Laboratory Standards (NCCLS, 1990). The inocula were prepared in $0-9 \% \mathrm{NaCl}$ from three to five colonies of overnight cultures and were adjusted to a turbidity equivalent to that of a McFarland 0.5 standard, corresponding to $c$. $10^{3} \mathrm{cfu} / \mathrm{mL}$. With a multipoint inoculating device (Cathra, MCT Diagnostics, MN, USA), $1 \mu \mathrm{L}$ of this inoculum was transferred to the surface of the antibiotic-containing Mueller-Hinton agar (Oxoid, Hampshire, UK). The final inoculum on the plates was $10^{4}$ to $10^{5} \mathrm{cfu} / \mathrm{spot}$.

The plates were incubated in air at $35^{\circ} \mathrm{C}$ for $20 \mathrm{~h}$, and thereafter were read by eye. The MIC of the antimicrobial was defined as the lowest concentration that completely inhibited growth, ignoring a faint haze of growth.

Microorganisms were screened for resistance to erythromycin with discs containing erythromycin $(15 \mu \mathrm{g})$ or clindamycin $(2 \mu \mathrm{g})$. Blunting of the clindamycin zone near the erythromycin disc was an indication of inducible resistance to the macrolidelincosamides-streptogramins group ( = inducible resistance to erythromycin); when no inhibition zone was seen around either antibiotic dises, resistance was considered to be constitutive.

\section{Antibiotic combination studies}

S-5556 was combined with the antimicrobials listed in Table III and evaluated with the chequerboard technique using a plate microdilution assay and Mueller-Hinton broth (Oxoid).

After an incubation of $20 \mathrm{~h}$ at $35^{\circ} \mathrm{C}$ the plates were read and the fractional inhibitory concentration (FIC) index determined. The FIC was defined as the lowest concentration of each of the two tested antimicrobials that had an inhibitory effect when acting together divided by the MIC of that drug alone, the sum of the FICs of the two antimicrobials being the FIC index. The tested antimicrobial combinations were interpreted as synergic when the FIC indices were $\leqslant 0.5$, additive when $0.5-0.75$, indifferent when $1-4$, and antagonistic when $>4$ (Krogstag \& Moellering, 1986).

\section{Prophylaxis of acute foreign body infection in guinea pigs}

Four polytetrafluoroethylene (Teflon) multiperforated tissue cages containing three polymethylmethacrylate (Plexiglas) coverslips were implanted subcutaneously in each guinea pig as previously described (Zimmerli et al., 1982). Three weeks later, after full healing of the incision, the animals were used for pharmacokinetic and prophylaxis studies.

The pharmacokinetic study was performed by taking blood $(n=3) 1,3,6$ and $10 \mathrm{~h}$ and tissue cage fluid $(n=8) 3,6,10,14,24$ and $36 \mathrm{~h}$ after the administration of $100 \mathrm{mg} / \mathrm{kg}$ (single dose) of S-5556 intraperitoneally to the guinea pigs. Concentrations of the drug in the serum and cage fluid were determined by a microbiological agar diffusion assay with Micrococcus luteus NCTC 8340.

In the prophylaxis study, tissue cages were checked for sterility and inoculated with $0.1 \mathrm{~mL}$ of saline containing c. $10^{2}$ or $10^{3} \mathrm{cfu}$ of $S$. aureus Wood 46, a methicillin-, erythromycin- and S-5556-susceptible strain (MIC of S-5556: $2 \mathrm{mg} / \mathrm{L}$ ); this was done $6 \mathrm{~h}$ after the injection of S-5556, to ensure a concentration of drug above the MIC in all 
cages at the time of inoculation. Without prophylactic treatment, $10^{2} \mathrm{cfu}$ are known to produce an infection in $>95 \%$ of the cages and $10^{3} \mathrm{cfu}$ regularly infect all the cages (Zimmerli et al., 1982). Quantitative cultures were performed $24,48 \mathrm{~h}$ and seven days after inoculation by plating $0.1 \mathrm{~mL}$ of tissue cage fluid, undiluted and ten-fold serially diluted, on Mueller-Hinton agar. The detection limit was $10 \mathrm{cfu} / \mathrm{mL}$. No significant carry-over of antibiotic was observed by using these experimental conditions. Agar plates were read after $48 \mathrm{~h}$ of incubation at $37^{\circ} \mathrm{C}$. On day 7, tissue cages were removed under strict aseptic conditions and coverslips were extracted from the cages, sonicated and cultivated in $5 \mathrm{~mL}$ of Mueller-Hinton broth and observed for one week. Control animals underwent the same procedure without receiving the drug. Results of prophylaxis with S-5556 were compared with those obtained with vancomycin in a previous study (Bouchenaki et al., 1990). In that study, vancomycin had boen administered as a single dose of $30 \mathrm{mg} / \mathrm{kg}$, with peak and 24-h tissue cage fluid concentrations of 50-fold and eight-fold the MIC, respectively.

\section{Treatment of chronic foreign body infection in rats}

As guinea pigs spontaneously expel infected subcutaneous foreign bodies after one to two weeks and rapidly suffer from severe diarrhoea under antimicrobial treatment, a model of chronic tissue cage infection was developed in rats, which allows more prolonged periods of therapy (Lucet et al., 1990). At three weeks after implantation, sterile tissue cages were injected with $1-5 \times 10^{3}$ cfu of $S$. aureus MRGR3, a methicillin-, gentamicin- and erythromycin-resistant, but S-5556-susceptible (MIC $=2 \mathrm{mg} / \mathrm{L}$ ) clinical isolate. Three weeks later, tissue cages containing $>1 \times 10^{5} \mathrm{cfu} / \mathrm{mL}$ of fluid ( $>90 \%$ ) were included in the pharmacokinetic and therapeutic protocols.

The pharmacokinetics of S-5556 were studied in 12 tissue cages after administration of the drug at a dosage of $100 \mathrm{mg} / \mathrm{kg}$ intraperitoneally every $24 \mathrm{~h}$ for four days. Drug concentrations were measured by bioassay on samples taken 1, 3, 6, 10, 14 and $24 \mathrm{~h}$ after injection.

In the therapeutic protocol, chronically infected rats received S-5556 for six days. Quantitative cultures of tissue cage fluid $(0-1 \mathrm{~mL}$, ten-fold serially diluted, incubation for $48 \mathrm{~h}$ at $37^{\circ} \mathrm{C}$ ) was performed on day one (before first dose) and day 7 (24 h after last dose) and expressed as $\log _{10} \mathrm{cfu} / \mathrm{mL}$. The detection limit was $100 \mathrm{cfu} / \mathrm{mL}$ but was never reached. No significant antibiotic carry-over occurred. At the end of treatment, resistant mutants to S- 5556 were searched for by plating $0.1 \mathrm{~mL}$ of $1 / 5$ diluted cage fluid on Mueller-Hinton agar plates containing S-5556 at a concentration of $10 \mathrm{mg} / \mathrm{L}$. $S$. aureus isolates which were found to be resistant to S-5556 were fully characterized by biochemical tests (API 32 Staph strip), susceptibility testing to a large panel of antibiotics, serotyping and phage typing.

As in the prophylactic study, results were compared with those of a control, untreated, group and with the results of a previous study (Lucet et al., 1990) where vancomycin was used ( $50 \mathrm{mg} / \mathrm{kg}$ twice a day for six days; peak concentration on day four: 15-fold the MIC, though concentration: seven-fold the MIC).

\section{Statistics}

In the prophylaxis protocol, the efficacy of S-5556 in reducing colony counts below the detection limit was compared with controls by chi-square test with Yates' correction. In 
Table II. Comparative in-vitro activity of macrolides and oxacillin for Staphylococcus spp. classified according to their susceptibility to erythromycin

\begin{tabular}{|c|c|c|c|c|}
\hline $\begin{array}{l}\text { Organism } \\
\text { (no. of strains) }\end{array}$ & Agent & $50 \%$ & $\begin{array}{c}\mathrm{MIC}(\mathrm{mg} / \mathrm{L}) \\
90 \%\end{array}$ & Range \\
\hline $\begin{array}{l}\text { Erythromycin-susceptible } \\
\text { staphylococei (34) }\end{array}$ & $\begin{array}{l}\text { S- } 5556 \\
\text { erythromycin } \\
\text { roxithromycin } \\
\text { oxacillin }\end{array}$ & $\begin{array}{l}1 \\
0-25 \\
0-5 \\
0-25\end{array}$ & $\begin{array}{l}2 \\
0-5 \\
0-5 \\
4\end{array}$ & $\begin{array}{l}0-25-2 \\
0-25-0-5 \\
0-12->32 \\
0-06->32\end{array}$ \\
\hline $\begin{array}{l}\text { Staphylococci with } \\
\text { inducible resistance } \\
\text { to erythromycin (13) }\end{array}$ & $\begin{array}{l}\text { S-5556 } \\
\text { erythromycin } \\
\text { roxithromycin } \\
\text { oxacillin }\end{array}$ & $\begin{array}{r}1 \\
16 \\
32 \\
32\end{array}$ & $\begin{array}{r}2 \\
>32 \\
>32 \\
>32\end{array}$ & $\begin{array}{r}1-2 \\
4->32 \\
4->32 \\
0-25->32\end{array}$ \\
\hline $\begin{array}{l}\text { Staphylococci with } \\
\text { constitutive resistance } \\
\text { to erythromycin (9) }\end{array}$ & $\begin{array}{l}\text { S-5556 } \\
\text { erythromycin } \\
\text { roxithromycin } \\
\text { oxacillin }\end{array}$ & $\begin{array}{r}>32 \\
>32 \\
>32 \\
32\end{array}$ & $\begin{array}{l}>32 \\
>32 \\
>32 \\
>32\end{array}$ & $\begin{array}{rl}> & 32 \\
& 32->32 \\
> & 32 \\
0 & 12->32\end{array}$ \\
\hline
\end{tabular}

the therapeutic protocol, the mean changes in bacterial counts between day 1 and 7 under S-5556 and without treatment were compared with Student's t-test (two-tailed).

Results

\section{In-vitro studies}

The inhibitory activity of the macrolides S-5556, erythromycin and roxithromycin as well as seven other antistaphylococcal agents on 56 Staphylococcus spp. is shown in Table I. For methicillin-susceptible $S$. aureus, the MICs of S-5556 were generally twice the value of those obtained for erythromycin and roxithromycin. For MRSA the MIC of all macrolides were $\geqslant 32 \mathrm{mg} / \mathrm{L}$. Nine of fifteen isolates moderately or highly resistant to erythromycin (MIC $4 \mathrm{mg} / \mathrm{L}$; in three and $\mathrm{MIC}>8 \mathrm{mg} / \mathrm{L}$ in 12) were inhibited by $\leqslant 2 \mathrm{mg} / \mathrm{L}$ of $\mathrm{S}-5556$; these nine isolates showed an inducible-type resistance to the macrolide-lincosomide-streptogramin group. When the 56 staphylococi were classified according to their susceptibility to erythromycin all isolates with inducible resistance to erythromycin were susceptible to S-5556, whereas those having constitutive resistance to erythromycin were also resistant to S-5556 (Table II).

The combination of S-5556 with vancomycin was indifferent except for one isolate where it was additive (Table III). The effect of combining S-5556 with oxacillin varied from indifference to synergy and was strain dependent. For oxacillin-susceptible isolates (MIC $<4 \mathrm{mg} / \mathrm{L}$ ) the combination was indifferent or additive (FIC index $>0-5$ ), but for oxacillin-resistant isolates (MIC $\leqslant 4 \mathrm{mg} / \mathrm{L}$ ) the combination acted synergically (FIC index $\leqslant 0.5$ ). The statistical evaluation of this observation for 21 Staphylococcus spp. (12 MRSA) revealed statistical significance $(P<0-05)$ when applying Fisher's exact test (two-tailed). The inhibitory activity of S-5556 was reduced by the quinolone ofloxacin such that in $2 / 7$ tested isolates an FIC index of $\geqslant 4$, an antagonistic effect, was observed. The combination S-5556 plus rifampicin was usually additive and strain-dependent, but there was no relationship between these results and a particular subgroup of staphylococci. 


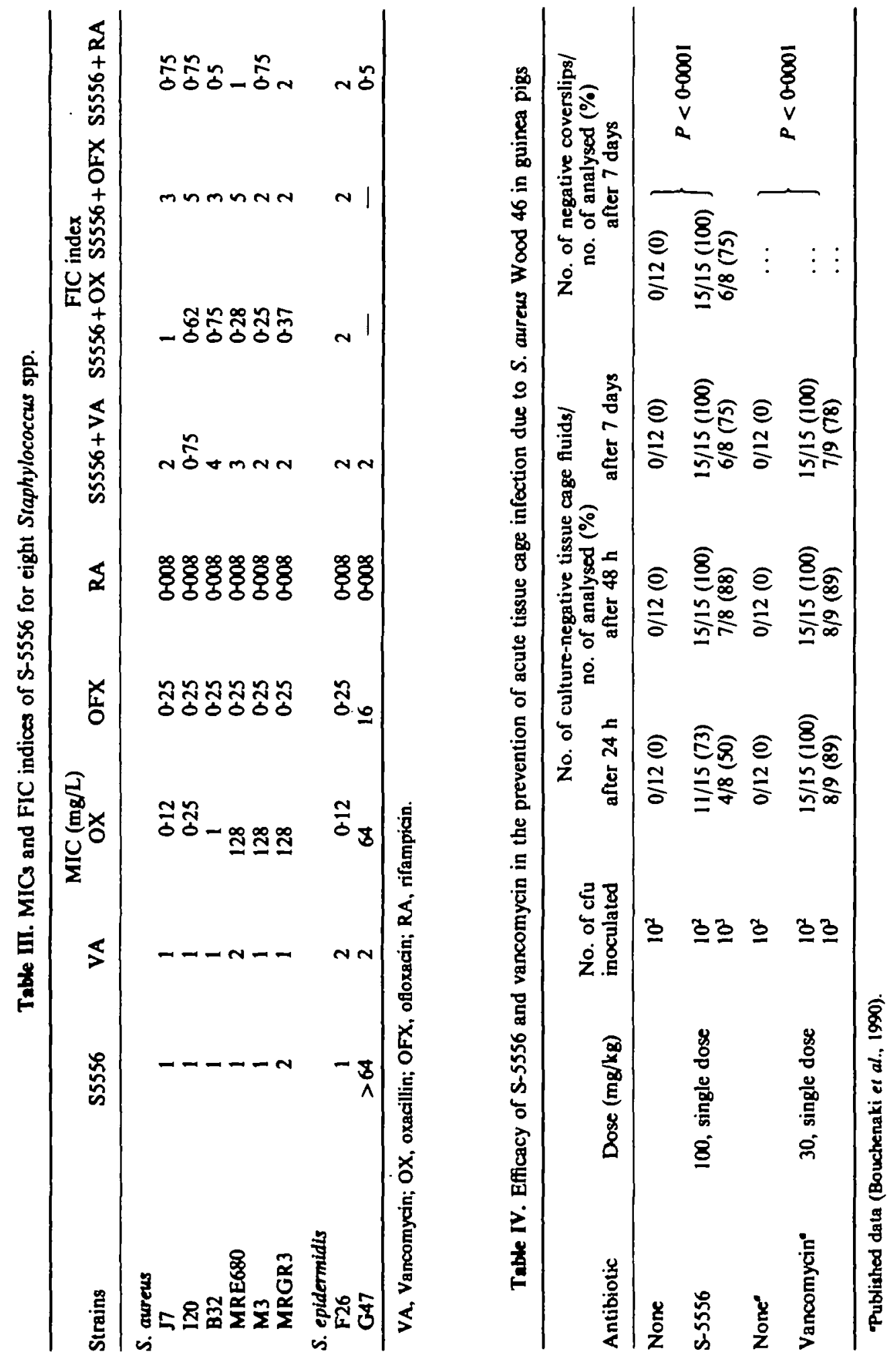




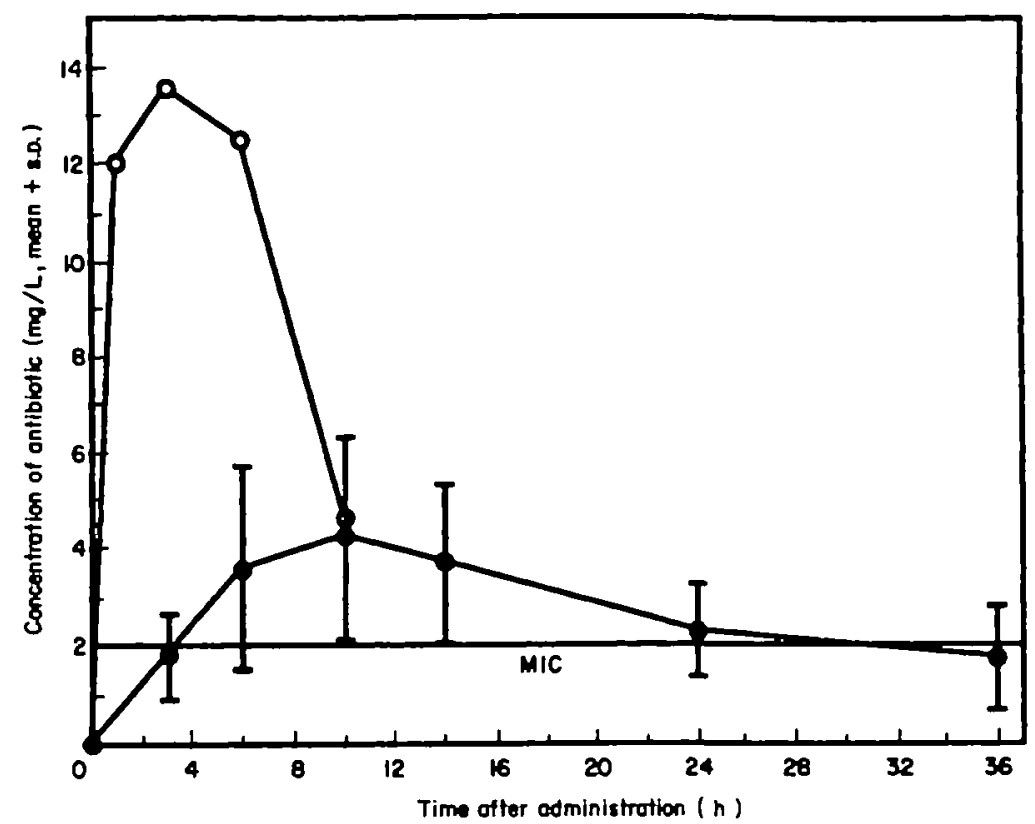

Fhywe 1. Prophylaxis of foreign body infection in guinea pigs. Pharmacokinetica of a single intraperitoneal dose of $100 \mathrm{mg} / \mathrm{kg} \mathrm{S}-5556$ in serum $(O)$ and tissue cage fluid $(O)$.

\section{Prophylaxis of acute foreign body infection in guinea pigs}

After a single dose of $100 \mathrm{mg} / \mathrm{kg}$, the mean peak serum concentration of S-5556 in guinea pigs was found to be $13.54 \mathrm{mg} / \mathrm{L}$ after $3 \mathrm{~h}$. The concentration in the tissue cage fluid was above the MIC from 4 to $28 \mathrm{~h}$ following administration, reaching maximal values of $4.23 \pm 2.11 \mathrm{mg} / \mathrm{L}$ (mean \pm S.D.) after $10 \mathrm{~h}$ (Figure 1).

Twenty-four hours after a challenge of $10^{2}$ cfu of $S$. aureus Wood $46,11 / 15(73 \%)$ tissue cage fluids yielded no bacteria on culture; after $48 \mathrm{~h}, 15 / 15$ were culture negative, a proportion which underwent no change after seven days. Culture of coverslips, placed in the cages as a control to exclude survival of small subpopulations of adherent bacteria, was negative in all cases; the direct culture of coverslips is the most sensitive procedure to assume that the foreign body is sterile. After the injection of $10^{3}$ bacteria, the number of negative fluids was $4 / 8(50 \%)$ at $24 \mathrm{~h}, 7 / 8(88 \%)$ at $48 \mathrm{~h}$ and $6 / 8(75 \%)$ at seven days, and $6 / 8(75 \%)$ coverslips were sterile when removed. All cultures were positive at all times for the control group $(P<0.0001)$. These results are similar to those obtained in a recent study with vancomycin using exactly the same protocol (Bouchenaki et al., 1990); at that time, the coverslips were not cultured (Table IV).

Treatment of chronic foreign body infection in rats

After four doses of $100 \mathrm{mg} / \mathrm{kg}$ of S-5556 in rats, the peak and trough levels in tissue cage fluid were $6.46 \pm 1.35 \mathrm{mg} / \mathrm{L}$ and $4.19 \pm 0.85 \mathrm{mg} / \mathrm{L}$, respectively (Figure 2).

At the beginning of treatment, bacterial counts of $S$. aureus MRGR3 in the tissue cage fluid were $678 \pm 1.05 \log _{10} \mathrm{cfu} / \mathrm{mL}$, with no statistically significant differences between the group receiving S-5556, the control group and a group of animals recently 


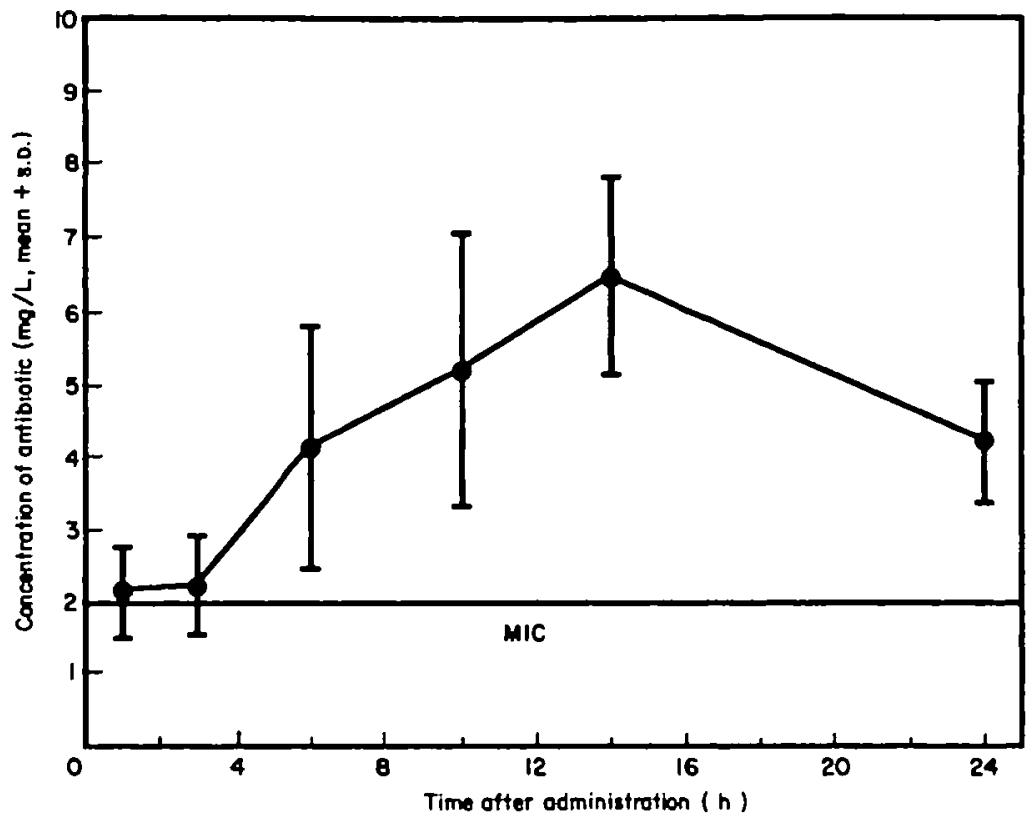

Figure 2 Treatment of foreign body infection in rats. Pharmacokinetica after four intraperitoneal doses every $24 \mathrm{~h}$ of S-5556 in tissue cage fluid.

treated with vancomycin using exactly the same protocol (Lucet et al., 1990). As shown in Table V, viable bacterial counts decreased $1.35 \pm 1.20 \log _{10} \mathrm{cfu} / \mathrm{mL}$ in cage fluid of rats treated for one week with S-5556, which was significantly more than in the control group $\left(0.01 \pm 0.96 \log _{10} \mathrm{cfu} / \mathrm{mL}\right.$ decrease, $\left.P<0.001\right)$ but in the range of the results previously obtained with vancomycin $\left(1 \cdot 16 \pm 0.59 \log _{10} \mathrm{cfu} / \mathrm{mL}\right.$ decrease) (Lucet et al., 1990).

In animals treated with S-5556, bacteria resistant to high concentrations $(>128 \mathrm{mg} / \mathrm{L})$ of this antibiotic were found in small numbers $\left(4.17 \times 10^{-3}-2.73 \times 10^{-3}\right)$ in $4 / 14$ cages on day 7 . Their biochemical pattern, serotype and phage type were similar to those of MRGR3. Except for resistance to S-5556, the susceptibility to antibiotics in the mutants was similar to that of MRGR3 in one case and there was the additional appearance of a resistance to clindmaycin in the three other cases.

Table V. Efficacy of S-5556 and vancomycin in the treatment of chronic tissue cage infection due to $S$. aureus MRGR3 in rats

\begin{tabular}{|c|c|c|c|c|}
\hline \multirow{2}{*}{$\begin{array}{l}\text { Antibiotic } \\
\text { None }\end{array}$} & \multirow[t]{2}{*}{ Dose (mg/kg) } & \multirow{2}{*}{ No. } & \multicolumn{2}{|c|}{$\begin{array}{c}\text { Mean decrease (s.D.) of bacterial counts } \\
\text { in tissue cage fluid after six days } \\
\text { of treatment }\left(\log _{10} \mathrm{cfu} / \mathrm{mL}\right)\end{array}$} \\
\hline & & & $0-01(0-96)$ & \\
\hline S-5556 & 100 , once-daily & 14 & $1.35(1.20)$ & \\
\hline None" & & 27 & $0.20(0-84)$ & \\
\hline Vancomycin" & so, bd & 16 & $1.16(0.59)$ & $P$ \\
\hline
\end{tabular}

Publizhed data (Lucet et al., 1990). 


\section{Discussion}

In vitro, S-5556 was slightly less active than erythromycin for methicillin-susceptible $S$. aureus. Other authors have observed similar results when several 16-membered macrolides (josamycin, spiramycin, miocamycin and rokitamycin) were compared with erythromycin (Fernandes \& Hardy, 1988). In contrast, MRSA were more often susceptible to S-5556 than to erythromycin due to the fact that in this group numerous strains had inducible resistance to erythromycin. Staphylococci with this type of resistance were uniformly susceptible to S-5556 in our study, and have previously been reported to be susceptible to other 16-membered macrolides (Fernandes \& Hardy, 1988; Hardy et al., 1988) while showing resistance to 14 and 15-membered macrolides (such as erythromycin, roxithromycin, clarithromycin, azithromycin, dirithromycin and flurithromycin). This property makes 16 -membered macrolides an attractive antibiotic class for the treatment of staphylococcal infections.

Among the different antimicrobial agents tested in combination with S-5556, only oxacillin was synergic and this effect was observed significantly more often with MRSA than with strains susceptible to oxacillin. A similar synergic phenomenon on MRSA has already been described with the combination of quinolones and oxacillin (Rohner et al., 1989). It has been shown that quinolones enhance the binding of oxacillin to penicillin-binding protein (PBP) 2' in MRSA (Lucain, Furet \& Pechère, 1991). Whether macrolides improve the activity of oxacillin by a similar mechanism remains to be studied.

Antistaphylococcal prophylaxis for surgical procedures involving the insertion of foreign material currently relies on the use of two bactericidal antibiotic classes, i.e. first-generation cephalosporins or vancomycin and derivatives when methicillin-resistant $S$. aureus is a possible pathogen and for patients allergic to $\beta$-lactam drugs (Kaiser, 1986; Anonymous, 1989). Rifampicin (Tshefu et al., 1983) and quinolones (Bouchenaki et al., 1990; Vaudaux et al., 1990) have proved effective in animal studies. The use of new macrolides in this setting has not been studied so far. The results of this study show that the efficacy of S-5556 was similar to that of vancomycin (Bouchenaki et al., 1990), with a complete protection against infection at $48 \mathrm{~h}$ and seven days after inoculation of the foreign body with $10^{2} \mathrm{cfu}$ of $S$. aureus. At $24 \mathrm{~h}$ after inoculation, several tissue cage fluids were culture-positive in animals receiving the macrolide, but only one with vancomycin. This early difference, which had no influence on the final outcome since all the cages became negative after $48 \mathrm{~h}$, is probably the result of the slower bactericidal activity of the macrolide. The results obtained with S-5556 were surprisingly good, especially with regard to the low concentrations of drug measured in tissue cage fluid. However, these concentrations were maintained above the MIC for more than $24 \mathrm{~h}$, which is probably an important condition for obtaining a protective effect (Vaudaux et al., 1990). The excellent penetration of macrolides into polymorphonuclear leucocytes and other phagocytic cells (Miller et al., 1984; Dette \& Knothe, 1986) is possibly also a key for success.

In the therapeutic model of chronic foreign body infection, when an erythromycinand methicillin-resistant $S$. cureus isolate was used, S-5556 had significant activity and yielded results in the range of those obtained previously with vancomycin (Lucet et al., 1990). As in the prophylaxis study, the concentrations of S-5556 were rather low in the tissue cage fluid but constantly exceeded the MIC. These promising results were, however, tempered by the emergence of resistant mutants to high drug levels in $29 \%$ of 
the cases. Emergence of resistance to erythromycin during treatment of staphylococcal infections was reported as early as 1952, shortly after the introduction of this antibacterial agent (Haight \& Finland, 1952; Lepper et al., 1953). Although in this model resistant bacteria were rare after seven days of treatment, a longer course of antibiotics would probably select mutants and lead to treatment failures. In previous studies on the treatment of experimental chronic staphylococcal foreign body infections (Lucet et al., 1990; Chuard et al., 1991a), it was shown that combined regimens (e.g. vancomycin and rifampicin or fleroxacin and rifampicin) were superior to single drug therapy, both for efficacy and prevention of emergence of resistant bacteria. Combined regimens including new macrolides might prove similarly useful in infections caused by staphylococci.

In conclusion, promising in-vitro and experimental in-vivo data were obtained with a new 16-membered macrolide against staphylococci, including erythromycin- and methicillin-resistant strains. This class of antibacterial substances, used alone or in combination with other antibiotics, deserves further evaluation for this indication.

\section{Acknowledgements}

This work was supported by grant 32-30161.90 from the Swiss National Research Foundation and by a grant of Servier (Neuilly-sur-Seine, France). C. Chuard is the recipient of fellowship 32-27222.89 from the Swiss National Research Foundation. We are indebted to Dr Y. Brun (Centre National de Reférence des Staphylocoques, Pr. J. Fleurette, Lyon, France) for performing serotyping and phage typing. We thank Manuela Bento for excellent technical assistance.

\section{References}

Anonymous, Leading Article. (1989). Antimicrobial prophylaxis in surgery. Medical Letter on Drugs and Therapeutics 31, 105-8.

Bouchenaki, N., Vaudaux, P. E., Huggler, E., Waldvogel, F. A. \& Lew, D. P. (1990). Successful single-dose prophylaxis of Staphylococcus aureus foreign body infections in guinea pigs by fleroxacin. Antimicrobial Agents and Chemotherapy 34, 21-4.

Chuard, C., Herrmann, M., Vaudaux, P., Waldvogel, F. A. \& Lew, D. P. (1991a). Successful therapy of experimental chronic foreign body infection due to methicillin-resistant Staphylococcus aureus by antimicrobial combinations. Antimicrobial Agents and Chemotherapy 35, 2611-6.

Chuard, C., Lucet, J.-C., Rohner, P., Herrmann, M., Auckenthaler, R., Waldvogel, F. A. et al. (1991b). Resistance of Staphylococcus aureus recovered from infected foreign body in vivo to killing by antimicrobials. Journal of Infectious Diseases 163, 1369-73.

Dette, G. A. \& Knothe, H. (1986). Kinetics of erythromycin uptake and release by human lymphocytes and polymorphonuclear leucocytes. Joumal of Antimicrobial Chemotherapy 18, 73-82.

Fernandes, P. B. \& Hardy, D. J. (1988). Comparative in vitro potencies of nine new macrolides. Drugs under Experimental and Clinical Research 14, 445-51.

Haight, T. H. \& Finland, M. (1952). Resistance of bacteria to erythromycin. Praceedings of the Society for Experimental Biology and Medicine 81, 183-8.

Hardy, D. J., Hensey, D. M., Beyer, J. M., Vojtko, C., McDonald, E. J. \& Fernandes, P. B. (1988). Comparative in vitro activities of new 14, 15-, and 16-membered macrolides. Antimicrobial Agents and Chemotherapy 32, 1710-9.

Hemmer, R. J., Vaudaux, P. \& Waldvogel, F. A. (1979). Methicillin potentiates the effect of gentamicin on methicillin-resistant Staphylococcus aureus. Antimicrobial Agents and Chemotherapy 15, 34-41. 
Kaiser, A. B. (1986). Antimicrobial prophylaxis in surgery. New England Journal of Medicine 315, $1129-38$.

Kirst, H. A. \& Sides, G. D. (1989a). New directions for macrolide antibiotics: structural modifications and in vitro activity. Antimicrobial Agents and Chemotherapy 33, 1413-8.

Kirst, H. A. \& Sides, G. D. (1989b). New directions for mactolide antibiotics: pharmacokinetics and clinical efficacy. Antimicrobial Agents and Chemotherapy 33, 1419-22.

Krogstad, D. J. \& Moellering, R. C. (1986). Antimicrobial combinations. In Antibiotics in Laboratory Medicine, 2nd edn (Lorian, V., Ed.), pp. 537-95. Williams \& Wilkins, Baltimore, MD.

Lepper, M. H., Dowling, H. F., Jackson, G. G., Moulton, B. \& Spies, H. W. (1953). Effect of antibiotic usage in the hospital on the incidence of antibiotic-resistant strains among personnel carrying staphylococci. Joumal of Laboratory and Clinical Medicine 42, 832.

Lucain, C., Furet, Y. X. \& Pechère, J. C. (1991). Synergistic effect of temafloxacin and oxacillin against MRSA. In Abstracts of the Seventeenth International Congress of Chemotherapy. Berlin, 1991. Abstract 1171. International Society of Chemotherapy, Berlin.

Lucet, J.-C., Herrmann, M., Rohner, P., Auckenthaler, R., Waldvogel, F. A. \& Lew, D. P. (1990). Treatment of experimental foreign body infection caused by methicillin-resistant Staphylococcus aureus. Antimicrobial Agents and Chemotherapy 34, 2312-7.

Miller, M. F., Martin, J. R., Johnson, P., Ulrich, J. T., Rdzok, E. J. \& Billing, P. (1984). Erythromycin uptake and accumulation by human polymorphonuclear leukocytes and efficacy of erythromycin in killing ingested Legionella pneumophila. Journal of Infectious Diseases 149, 714-8.

National Committee for Clinical Laboratory Standards (1990). Methods for Dilution Antimicrobial Susceptibility Tests for Bacteria that Grow Aerobically-2nd edn; Approved Standard M7-A2. NCCLS, Villanova, PA.

Rohner, P., Herter, C., Auckenthaler, R., Pechère, J.-C., Waldvogel, F. A. \& Lew, D. P. (1989). Synergistic effect of quinolones and oxacillin on methicillin-resistant Staphylocaccus species. Antimicrobial Agents and Chemotherapy 33, 2037-41.

Ruggeri, C., Laborde, M. A., Dessinges, A., Ming, L., Olesker, A. \& Lukacs, G. (1989). Synthesis and antibacterial activity of 9-O-((2-methoxyethoxy)methyl)-oximes of tylosin and demycarosyltylosin. Journal of Antibiotics 42, 1443-5.

Steigbigel, N. H. (1990). Erythromycin, lincomycin, and clindamycin. In Principles and Practice of Infectious Diseases, 3rd edn (Mandell, G. L., Douglas, R. G. \& Bennett, J. E., Eds), pp. 308-17. Churchill Livingstone, New York.

Tshefu, K., Zimmerli, W. \& Waldvogel, F. A. (1983). Short-term administration of rifampin in the prevention or eradication of infection due to foreign bodies. Reviews of Infectious Diseases 5, Suppl. 3, S474-80.

Vaudaux, P., Huggler, E., Waldvogel, F. A. \& Lew, D. P. (1990). Evaluation of single- and double-dose prophylaxis of Staphylococcus aureus foreign body infection in a guinea pig model by ofloxacin and other antimicrobial agents. In Boak of Abstracts of the Third International Symposium on New Quinolones, Vancouver, 1990. Abstract 104.

Vaudaux, P. \& Waldvogel, F. A. (1979). Methicillin-resistant strains of Staphylococcus aureus. relation between expression of resistance and phagocytosis by polymorphonuclear leukocytes. Journal of Infectious Diseases 139, 547-52.

Zimmerli, W., Waldvogel, F. A., Vaudaux, P. \& Nydegger, U. E. (1982). Pathogenesis of foreign body infection: description and characteristics of an animal model. Journal of Infectlous Diseases 146, 487-97.

(Recelved 3 October 1991; revised version accepted 26 March 1992) 